\title{
The Search and Seizure of Digital Evidence by Forensic Investigators in South Africa
}

JGJ Nortjé $e^{\star}$ and DC Myburgh ${ }^{\star *}$

\section{P.E.R}

Pioneer in peer-reviewed, open access online law publications

\section{Authors}

Jacobus GJ Nortjé

Daniel C Myburgh

Affiliation

North-West University

South Africa

Email

Koos.Nortjie@nwu.ac.za dc@cyanre.co.za

Date Submission

6 April 2018

Date Revised

\section{April 2019}

\section{Date Accepted}

5 April 2019

Date published

25 April 2019

Editor Prof C Rautenbach

How to cite this article

Nortjé JGJ and Myburgh DC "The Search and Seizure of Digital Evidence by Forensic Investigators in South Africa" PER / PELJ 2019(22) DOI http://dx.doi.org/10.17159/17273781/2019/v22i0a4886

\section{Abstract}

The discipline of digital forensics requires a combination of skills, qualifications and knowledge in the area of forensic investigation, legal aspects and information technology. The uniqueness of digital evidence makes the adoption of traditional legal approaches problematic.

Information technology terminology is currently used interchangeably without any regard to being unambiguous and consistent in relation to legal texts. Many of the information technology terms or concepts have not yet achieved legal recognition.

The recognition and standardisation of terminology within a legal context are of the utmost importance to ensure that miscommunication does not occur.

To provide clarity or guidance on some of the terms and concepts applicable to digital forensics and for the search and seizure of digital evidence, some of the concepts and terms are reviewed and discussed, using the Criminal Procedure Act 51 of 1977 as a point of departure.

Digital evidence is often collected incorrectly and analysed ineffectively or simply overlooked due to the complexities that digital evidence poses to forensic investigators. As with any forensic science, specific regulations, guidelines, principles or procedures should be followed to meet the objectives of investigations and to ensure the accuracy and acceptance of findings. These regulations, guidelines, principles or procedures are discussed within the contex of digital forensics: what processes should be followed and how these processes ensure the acceptability of digital evidence. These processes include international principles and standards such as those of the Association of Chiefs of Police Officers and the International Organisation of Standardisation. A summary is also provided of the most influential or best-recognised international (IOS) standards on digital forensics.

It is concluded that the originality, reliability, integrity and admissibility of digital evidence should be maintained as follows:

- Data should not be changed or altered.

- Original evidence should not be directly examined.

- Forensically sound duplicates should be created.

- Digital forensic analyses should be performed by competent persons.

- Digital forensic analyses should adhere to relevant local legal requirements.

- Audit trails should exist consisting of all required documents and actions.

- The chain of custody should be protected.

- Processes and procedures should be proper, while recognised and accepted by the industry.

If the ACPO (1997) principles and ISO/IEC 27043 and 27037 Standards are followed as a forensic framework, then digital forensic investigators should follow these standards as a legal framework.

\section{Keywords}

Digital forensics; digital devices; digital search and seizure; digital evidence; forensic investigation; international standards. 


\section{Introduction}

The discipline of digital forensics requires a combination of skills, qualifications and knowledge in the area of forensic investigation, legal aspects and information technology. ${ }^{1}$ In many academic papers and court cases information technology terminology is used interchangeably without any regard to its being unambiguous and conducive to consistent interpretation of terminology in a legal context, which is why information technology terminology is largely unknown in the legal system. ${ }^{2}$ Many information technology terms or concepts have not yet achieved legal recognition. This notion is supported by the South African Law Reform Commission (hereafter SALRC), ${ }^{3}$ which has expressed the opinion that the earlier opinion that computers are "just like" filing cabinets does not hold true in the light of new technological capabilities. This was also the opinion of the Supreme Court in the Canadian case $R v V u{ }^{4}$

Accurate legal definitions are vital to the operation of legal instruments, where words signify concepts in law, and the vocabulary consists of technical or legal terms and non-technical terms found in everyday language. ${ }^{5}$ Many of the words used in legal discourse are derived from ordinary language, but the true development of legal terminology - to a great extent - is derived from legal discourse in courts and depends less on the parameters set for communication with regard to generally recognised legal science principles. ${ }^{6}$ The recognition of terminology within a legal context is of the utmost importance to ensure that miscommunication does not occur. One should bear in mind that an initial understanding of texts may not be the only plausible interpretation. ${ }^{7}$ This can especially be true in a digital environment where technical aspects can have an influence on the normal interpretation or understanding of terms. Although one acceptable

Jacobus Gerhardus Johannes Nortjé. BCom Hons Business Administration MBA MCom Forensic Accounting (NWU) (FP)SA CFE. Associated Professor of Forensic Accounting and Forensic Investigation Management, North-West University, South Africa. Email: Koos.Nortje@nwu.ac.za.

** Daniel Christoffel Myburgh. BCom Hons Information Systems MCom Forensic Accounting (NWU). MCom Forensic Accounting Student North-West University, South Africa.Email: dc@cyanre.co.za.

Kessler Judges' Awareness 1.

Kessler Judges' Awareness 2.

SALRC Issue Paper 278.

$R v$ Vu 20133 SCR 657 (SCC).

Jopek-Bosiacka 2011 Research in Language 9.

Jopek-Bosiacka 2011 Research in Language 10, 14.

Clark and Connolly $2006 \mathrm{https}: / /$ www.law.georgetown.edu/academics/academicprograms/legal-writing-scholarship/writing-center/upload/statutoryinterpretation.pdf 2. 
meaning is the ideal, the interpretation of legal texts causes frequent problems, as the meaning denoted in texts may not be the same for all addressees. ${ }^{8}$ In 1958 Hart $^{9}$ encapsulated this issue perfectly by stating that in the most elementary form of law, the terms used should exist in some standard instance in which no doubt exists about their interpretation. Hart ${ }^{10}$ is of the opinion that there should be a "core of settled meaning".

In an attempt to provide clarity or guidance on some of the terms and concepts applicable to digital forensics and for the search and seizure of digital evidence, some of the concepts and terms are reviewed and discussed below.

In the early 1900s Dr Edmond Locard developed one of the cornerstones of modern-day forensic science, the Locard's exchange principle. ${ }^{11}$ While studying medicine Locard developed an interest in the application of science to legal matters. ${ }^{12}$ Locard theorised that every time a person or an object comes into contact with another, this results in an exchange of physical materials. Locard believed that during this contact all sorts of evidence, including human deoxyribonucleic acid (DNA), fingerprints, footprints, hair, skin cells, blood, bodily fluids, pieces of clothing, fibres and more are exchanged..$^{13}$ As early as in 1997 Silvernail ${ }^{14}$ stated that when persons start to use a computer, evidence of activities is created. It is therefore recognised that the Locard principle also applies to computers ${ }^{15}$ due to the evidential traces or artefacts exchanged between the network of victims and the computers of perpetrators. This is confirmed by Wang, ${ }^{16}$ who emphasises the fact that digital evidence can prove crucial links between victims and perpetrators.

If it is recognised that computers have become an attractive medium for criminals ${ }^{17}$ and that their activities on computers result in evidence that can

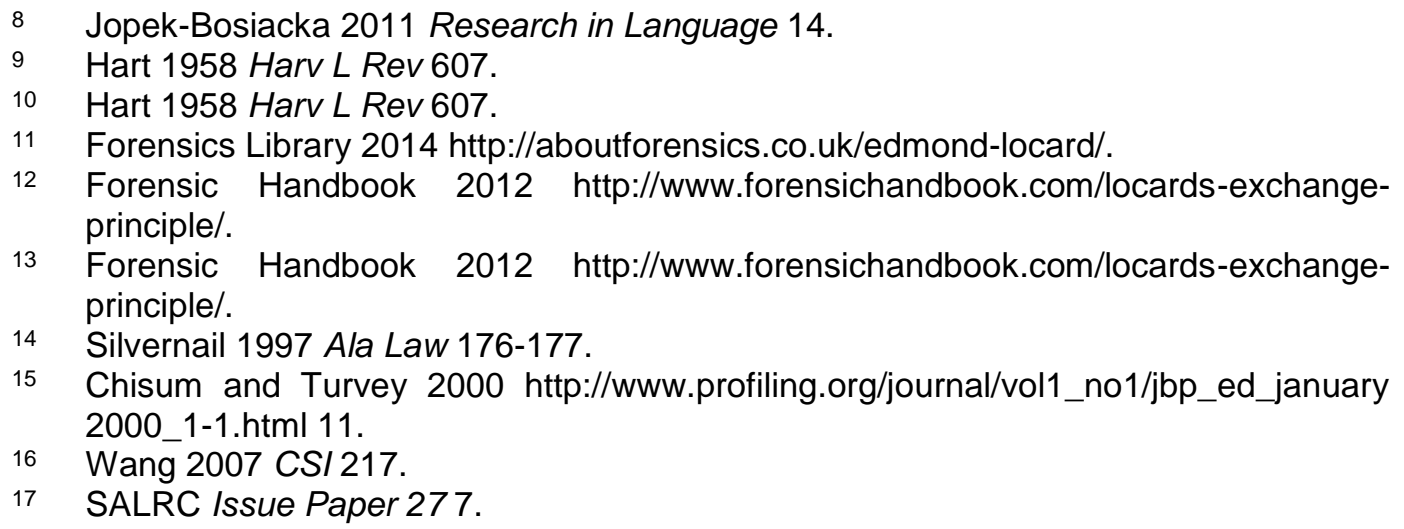


be linked to the crimes of suspects, ${ }^{18}$ it is essential to recognise the need for a discipline in the field of digital forensics.

Digital evidence is often collected incorrectly and analysed ineffectively or simply overlooked due to the complexities that digital evidence poses to forensic investigators. ${ }^{19}$ This "new" type of evidence has prompted the beginning of a "new" type of forensic science - digital forensics. ${ }^{20}$ As with any forensic science, specific regulations, guidelines, principles or procedures should be followed to meet the objectives of investigations, namely the accuracy and acceptance of findings. ${ }^{21}$ These regulations, guidelines, principles or procedures are discussed in the context of digital forensics: what processes should be followed and how these processes ensure the acceptability of digital evidence.

A summary is also provided of the most influential or best-recognised international standards on digital forensics.

\section{Terminology}

\subsection{Sections 20 and 21 of the Criminal Procedure Act 51 of 1977}

Section 21 of the Criminal Procedure Act 51 of 1977 relates to the power of authorised officials to issue search and seizure warrants.

The section furthermore authorises the police official to search and seize section 20 articles:

- $\quad$ which are concerned;

- $\quad$ which may afford evidence;

- which are intended to be used in the commission of a crime.

From this section, four concepts require further scrutiny on how these definitions relate to the digital environment, namely:

- $\quad$ search;

Casey Handbook of Computer Crime 1, 6.

19 Casey Handbook of Computer Crime 8; Craiger and Shenoi Advances in Digital Forensics 49.

20 Kerr 2005 Miss LJ 86.

21 Vacca Computer Forensics 6. 
- seize;

- articles;

- $\quad$ premises.

The intrusive nature of search and seizure warrants and the obligation of the judicial system to guard against the misuse of this authority are welldocumented in the case of Powell $v$ Van der Merwe. ${ }^{22}$ During this case, it was said that South African law has a long history of scrutinising search and seizure warrants with rigour and exactitude and that the common law rights are now enshrined in section 14 of the Constitution of the Republic of South Africa, 1996. Because of the danger of misuse during the application of authority with regard to search and seizure warrants, the judiciary scrutinises the validity of warrants with jealous regard for the liberty of suspects and their rights. The scope of the terms is even more relevant in cases involving digital evidence due to the wide scope of personal and confidential information kept on the digital devices of persons. ${ }^{23}$

The Explanatory Report to the Convention on Cybercrime of the Council of Europe suggests that additional procedural provisions are necessary in order to ensure that data can be secured in a manner as effective as in the case of the search and seizure of tangible objects. ${ }^{24}$ This is firstly because the data are intangible - they are in an electromagnetic medium. Secondly, while data can be read by making use of computer equipment, data cannot be taken away in the same sense as paper records. ${ }^{25} \mathrm{Kerr}^{26}$ captures some of the complexities of digital evidence as follows: "How can the old rules fit the new facts? For example, what does it mean to 'search' computer data, or when is computer data 'seized'?" The Explanatory Report to the Convention on Cybercrime further suggests that data can be "seized" in only a specific number of ways, namely data can be printed and seized; the tangible medium upon which data is stored can be seized; or a forensic duplicate can be made of the data and the tangible form upon which the copy is saved can be seized. It is suggested that domestic law should provide for the power to create such duplicates. ${ }^{27}$

\footnotetext{
Powell $v$ Van der Merwe 20051 All SA 149 (SCA). Guzzi 2012 Am Crim L Rev 302.



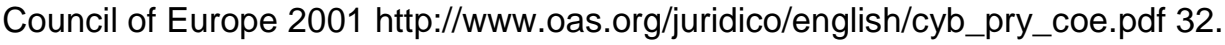
Kerr 2005 Harv L Rev 533.

Council of Europe 2001 http://www.oas.org/juridico/english/cyb_pry_coe.pdf 32.
} 


\subsubsection{Defining the search for digital evidence}

Kerr ${ }^{28}$ suggests that forensic investigators should first search for and locate physical devices ("search one"). Then, forensic investigators should access and search these physical devices for relevant information or data ("search two"). For the purpose of this article, references to "search" are extended from Kerr's two-step process to include three phases, namely:

- The traditional process in which forensic investigators search for or locate physical computers on a scene.

- The forensic investigators search for or segregate relevant and nonrelevant information/data on these computers.

- The analysis or interpretation of relevant information within the context of a larger investigation.

This discussion of the definition of "search" relates to the later steps followed when data is searched, since it is acknowledged that the search for physical articles on premises is well-defined and understood in the law.

The phenomenon of seizing's taking place before a search has taken place is discussed by Brenner and Fredericksen, ${ }^{29}$ who state that a search and seizure of digital evidence turns a normal search and seizure on its head in the sense that computers are normally first seized and then searched. In the case of the Minister of Safety and Security v Bennett, ${ }^{30}$ it was recognised that in instances where large collections of physical documents are located on a scene, and when it is impractical to separate or effectively search these documents on the scene, a broad seizure of the collection of physical documents is permitted, pending a later search to segregate relevant and non-relevant information.

The Explanatory Report to the Convention on Cybercrime proposes that traditional words such as "search" and "seize" should be replaced with more technological-orientated computer terms, such as "access" and "copy". ${ }^{31}$ This proposal is supported by Nieman, ${ }^{32}$ who is of the opinion that "search and seize" can more accurately described when computer terminology is used that is more neutral in meaning and can include actions, such as the

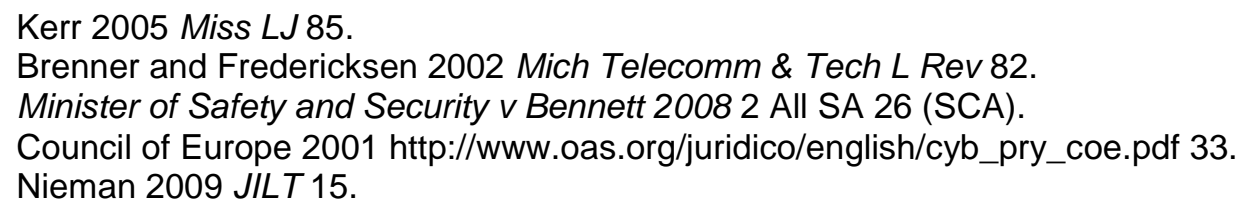


creation of forensic duplicates of data. Currently, in the consultation draft of the proposed South African Cybercrimes and Cybersecurity Bill dated 19 June 2016 the term "access" is included and is defined as follows: "to make use of, to gain entry to, to view, display, instruct, or communicate with, to store data in or retrieve data from, to copy, move, add, change, or remove data or otherwise to make use of, configure or reconfigure any resources of a computer device". ${ }^{33}$

In the Minister of Safety and Security $v$ Xaba case ${ }^{34}$ it was stated that the concept of "search" should be given its ordinary meaning. The National Instruction 2/2002 of the South African Police Service (SAPS) ${ }^{35}$ states that "search" entails any action whereby a person, premise or container is visually or physically examined with the aim of establishing whether an item or article is in, on or upon such a person, premises or container. However, Basdeo $^{36}$ is of the opinion that this approach is questionable since "visually" is not defined and can include merely looking at something. Furthermore, the question of what constitutes a search is left to common sense accessed on a case-by-case basis. Basdeo continues and argues that an element of physical intrusion is required to constitute a search of persons, premises or properties.

Merely observing a room does not constitute a fully-fledged search. ${ }^{37} \mathrm{Kerr}{ }^{38}$ proposes that an "exposure-based approach" should be adopted and that data should be considered to have been "searched" only when the data were exposed to human observation.

Basdeo ${ }^{39}$ states that the Council of Europe Convention on Cybercrime (2001) in Budapest (hereafter Budapest Convention) constitutes the current international agreed-upon benchmark for procedural powers in terms of digital evidence collection. The Budapest Convention proposes that "search" should include "to seek, read, inspect or review data", which includes the searching or examining of data. ${ }^{40}$

The interpretation of "search" as an "exposure-based approach" is supported and based on any action in which forensic investigators access

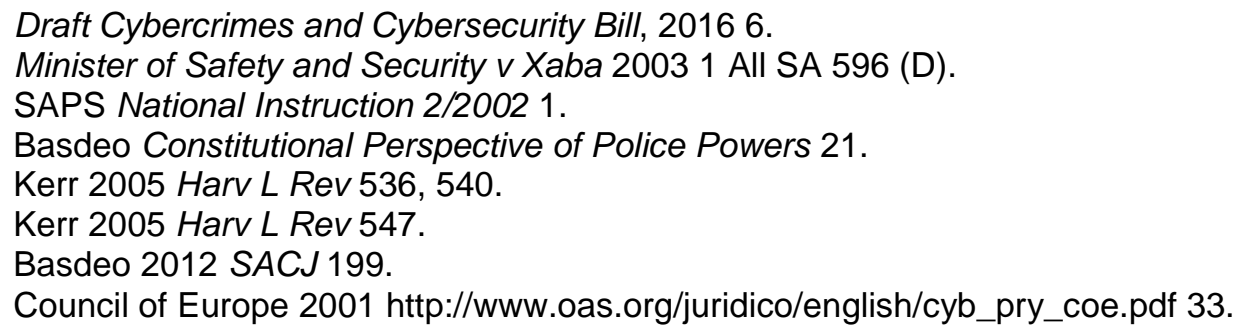


data by whatever means and take notice of information or observe information in a humanly readable format. It is recognised that the term "search" is extraordinarily broad, and a differentiation is made between the different contexts of search, as an action to firstly locate or look for devices on a scene; secondly, to locate and separate relevant and non-relevant data; and lastly, to analyse or interpret the data within the context of a larger investigation.

\subsubsection{Defining the seizure of digital evidence}

In the Rudolph $v$ Commissioner for Inland Revenue case ${ }^{41}$ the court held that the term "seize" should be given its natural meaning. This ruling was supported in the case of Ntoyakhe $v$ Minister of Safety and Security, ${ }^{42}$ when the court held that "seize" means not only to take possession of articles but also to retain them and, according to Steytler, ${ }^{43}$ to deprive persons of subsequent control over the articles. Nieman ${ }^{44}$ adds that a seizure takes place when persons are deprived of their control over articles, and without the subsequent right of retention of the articles section 21 of the Criminal Procedure Act would be worthless. In the Ntoyakhe $v$ Minister of Safety and Security case, it was cautioned that the right of retention is not unlimited and does not authorise the State to deprive persons of their lawful possession of articles indefinitely. ${ }^{45}$ This is a very important issue raised by the court. Although sections 31 to 36 of the Criminal Procedure Act govern the disposal of articles under various conditions, no explicit reference is made to the duration in days for which articles may be retained after the point of seizure, or when forensic duplicates are made when the original articles are to be returned following the creation of the duplicates. The situation with computers differs from that of other classes of articles because computers and other digital devices such as cellular phones play such a large role in our everyday lives. The retention period under discussion does not refer to the retention of forensic duplicates of computers during an analysis phase, but to the period between the seizure of computers on a scene, the creation of off-site forensic duplicates, and the subsequent return of the original computers to the owners. In many countries, legislation stipulates a time period in a number of days for this retention period. In an unstructured interview, ${ }^{46}$ it was established that the practice in South Africa - due to there




being limited resources - is that police officials in the most cases seize computers on scenes and then transfer articles to central digital forensic laboratories. During this interview, it was stated that some of the digital forensic laboratories are months - even more than a year - behind in their workload. ${ }^{47}$ The interviewee ${ }^{48}$ estimated that on average persons are deprived of their computers (or cellular phones) for between five days to two years.

In the light of the unique way in which digital evidence is normally collected or "seized", Kerr"4 poses a number of questions with regard to the interpretation of when digital evidence is considered seized, namely:

- Does the creation of forensic duplicates constitute a seizure?

- Does the creation of forensic duplicates constitute a seizure of original evidence?

- If forensic duplicates are searched, does this constitute a seizure?

Kerr ${ }^{50}$ states that these aspects are surprisingly difficult to interpret and at first sight it seems sensible to say that the creation of forensic duplicates constitutes a seizure of evidence. In the United States case of Arizona $v$ $H i c k s^{51}$ an investigator copied the serial number on a stereo system to establish later whether or not it was stolen goods. The court held that the copying of this information did not constitute a seizure. The court also held that the recording, copying or taking of a photograph of information on a scene does not constitute a seizure. This finding highlights the question whether forensic duplicates of computers constitute a seizure. Kerr ${ }^{52}$ further reviewed these complexities by arguing that if the creation of forensic duplicates is not recognised as constituting a search and seizure - since the data were not exposed, read or observed by humans, but only forensically duplicated - this could drastically expand the powers of the forensic investigators. In addition, Kerr maintains that should the making of forensic duplicates not be viewed as a search and seizure, the forensic investigators would not need search and seizure warrants, and Kerr refers to such a situation as "troublesome" and downright "creepy".

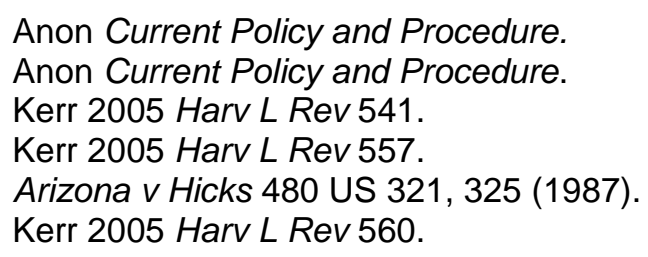


The Explanatory Report to the Convention on Cybercrime ${ }^{53}$ proposes that "seize" should also include "to take away the physical medium which stores the data" or to make and retain forensic duplicates of data. This proposal is supported by Basdeo, ${ }^{54}$ who is of the opinion that the seizure of data includes not only the confiscation of data but also the "gathering" of data.

The concept of seizure is important, and it is therefore necessary to consider the way in which and the reason why forensic duplicates are created. Nieman ${ }^{55}$ explains that forensic duplicates do exactly what the name suggests - bit-by-bit exact duplicates of every sector of a hard drive are created. The requirement of section 14 of the Electronic Communications and Transactions Act 25 of 2002 relating to the originality of evidence stipulates that where the law requires information to be presented or retained in its original form, that requirement is met if the integrity of the digital evidence from the time it was first generated to its final form has passed assessment. Vacca ${ }^{56}$ states that a new concept of representational accuracy has emerged in terms of digital evidence - it is not necessary anymore to present the original. If forensic duplicates are created that depict the source data exactly, these duplicates can be considered originals. However, after forensic duplicates of computers are created and the originals are handed back to suspects, as soon as a person switches on the computer the content of that computer changes on a continual basis. ${ }^{57}$

The proposed Cybercrimes and Cybersecurity Bill provides a more inclusive definition for "seize" by including the rendering of data inaccessible, the removal of physical devices, to make or retain forensic duplicates, or to make a printout of data. ${ }^{58}$ For the purposes of this article, the interpretation of "seizure" includes the creation of forensically-sound duplicate originals, and the seizure or retention of these duplicates is viewed by the State as originals.

\section{Defining premises and containers}

Section 1 of the Criminal Procedure Act defines "premises" as "including land, any building or structure, or any vehicle, conveyance, ship, boat or aircraft". It is questioned whether this definition permits the inclusion of a computer as a premises and does this definition permit the search of

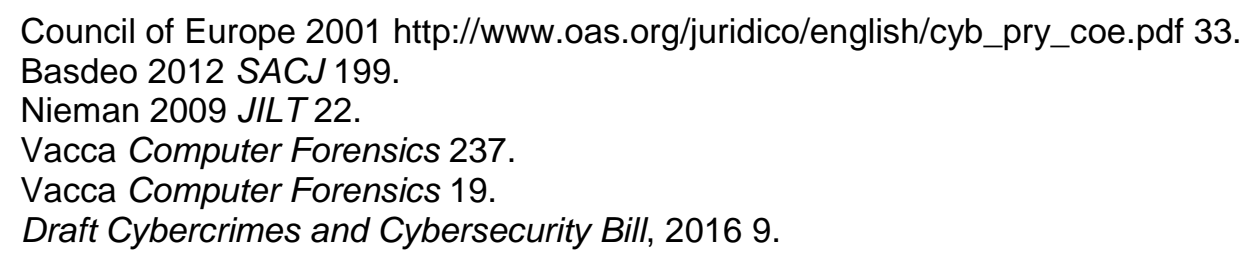


computers prior to seizure? In their Discussion Paper on Computer-related Crime $^{59}$ the SALRC is of view that the provisions of the Criminal Procedure Act were developed prior to the notion that non-physical premises or nontangible articles exist, and the commission is of the opinion that chapter two of the Criminal Procedure Act most probably does not apply to the search of computers and the seizure of data located on computers. They recommend that the Criminal Procedure Act be amended to specifically include the search of computers and the seizure of data. Section 82(4) of the Electronic Communications and Transactions Act stipulates, "For the purposes of this Act, any reference in the Criminal Procedure Act, 1977, to 'premises' and 'article' includes an information system as well as a data message". Unfortunately, the new Cybercrimes and Cybersecurity Bill is silent in this regard and does not provide a wider, more inclusive definition, but recognises the searching of containers. ${ }^{60}$ This definition is also supported by the National Instruction 2/2002 of the SAPS, where it states that a search entails any action whereby persons, premises or containers are visually or physically examined with the aim of establishing whether items or articles are in, on or upon such persons, premises or containers. ${ }^{61}$

In 2012, the Seventh Circuit Court in the case of the United States $v$ FloresLope $^{62}$ defined containers as any objects containing anything else including data. The court held that smartphones or tablets comply with this definition and can therefore be searched.

The court held in the Thint (Pty) Ltd $v$ National Director of Public Prosecutions, Zuma $v$ National Director of Public Prosecutions case ${ }^{63}$ that it is a requirement in a South African environment that "premises" should be clearly defined. The question is then raised that if off-site searches of computers are permitted, what premises should be specified in warrants? Traditionally, premises are where suspects are located, but the presence of computers turns the search and seizure process around: the seizure of computers takes place on a scene but the search of data takes place at the premises of forensic investigators. Should the premises of suspects be listed, or the premises of forensic investigators or should computers be listed as premises? The answer was provided by the court during the

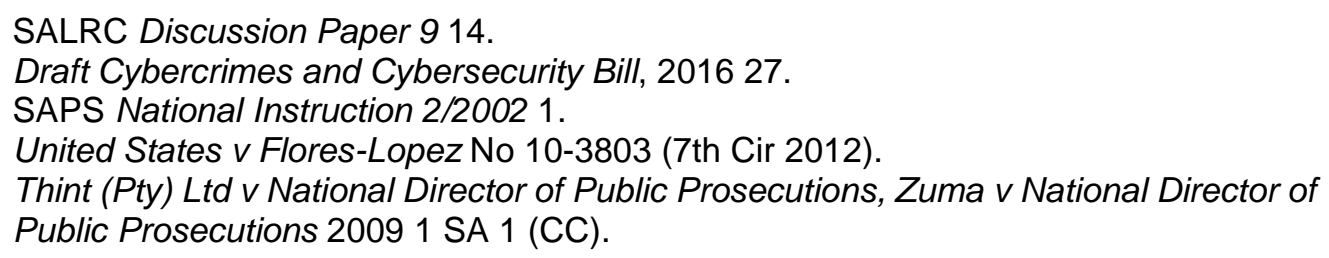


Minister of Safety and Security $v$ Bennett case,${ }^{64}$ where the seizing of physical documents - prior to the search of these documents off-site - was permitted without a description of the secondary premises of the forensic investigators. In the unreported judgement of Bennett $v$ Minister of Safety and Security, ${ }^{65}$ the court also expressed the opinion that it is irrelevant where forensic duplicates are created after the seizure and removal from the scene.

Another issue is raised in this regard - if forensic investigators are planning to seize data on another network or at an online location, do the search and seizure warrants need to state the physical location from which the forensic investigators are accessing the data or the physical location of where the data are kept? ${ }^{66}$ At the time when Kerr studied these aspects in 2005, cloud hosting was not as prevalent as it is today. If forensic investigators need to seize the files of persons kept in a virtual environment - hosted in a cloud what premises need to be described? Search and seizure is further complicated by the structure of cloud hosting, where one document can be broken up into a number of segments and each segment can be stored on a different server in a different country. The implications of this issue on search and seizure are recognised by the Australian Crimes Act ${ }^{67}$ and the New Zealand Search and Surveillance Act, ${ }^{68}$ both of which permit law enforcement to search remote locations, such as online data storage facilities with no physical addresses or specific singular location, such as cloud services, or where the physical locations are unknown.

For the purpose of this article, the interpretation of "premises" is limited to the traditional description of premises or locations and not extended to describing devices as separate premises or the premises of digital forensic investigators.

\section{Defining articles or items}

Bouwer ${ }^{69}$ observes that the Criminal Procedure Act is lacking in that it does not specifically include data as articles, and stated that the legislature has recognised this omission by referencing the definition of articles and premises in the Electronic Communications and Transactions Act, which

\footnotetext{
64 Minister of Safety and Security v Bennett 20082 All SA 26 (SCA).

65 Bennett $v$ Minister of Safety and Security (TPD) (unreported) case number $10828 / 2005$ of 13 May 200511.

66 Kerr 2005 Miss LJ 104.

67 Section 3LB of the Australian Crimes Act 12 of 1914.

68 Section 111 of the Search and Surveillance Act 24 of 2012.

69 Bouwer 2014 SACJ 171.
} 
states that data messages are classified as articles if these messages relate to a section 20 article as defined by the Criminal Procedure Act. Basdeo 70 states that "data" refers to information that has been transformed into digital form and in terms of the provisions made in section 20 of the Criminal Procedure Act, which stipulates that anything can be seized and that anything should be susceptible to a wide enough interpretation to include data. Notwithstanding, Basdeo further advises that the provisions made in the Criminal Procedure Act should be restructured to alleviate the restrictive interpretation that "articles" are only physical items. Basdeo further expresses the opinion that law enforcement is currently interpreting "articles" very widely, and applies this definition to the seizure of digital evidence - a practice that has not yet been contested in court. This aspect is addressed in the Cybercrimes and Cybersecurity Bill, which defines an "article" as any data, computer devices, computer networks, databases, critical databases, electronic communication networks or national critical information infrastructures or any part thereof or any other information, instruments, devices or equipment. ${ }^{71}$

For the purpose of this paper, the interpretation of "articles" or "items" as per the proposed Cybercrimes and Cybersecurity Bill is supported to include data, data storage devices and data processing devices.

\subsection{Defining data and data messages}

Article 1(b) of the Budapest Convention defines computer data as any representation of facts, information or concepts in a form suitable for being processed on computers. The SALRC states that the definition provided by the Electronic Communications and Transactions Act of "data" and "data messages" is based on Article 2 of the United Nations Commission on International Trade Law's (UNCITRAL) Model Law on Electronic Commerce with Guide to Enactment, ${ }^{72}$ which uses "data" and "data message" instead of the terms "electronic evidence" or "digital evidence". ${ }^{73}$ This approach is also recommended by the Practical Guide of the SAPS, ${ }^{74}$ which uses the term "data" instead of "digital evidence". The accurate use of terminology in search and seizure warrants in line with enabling legislation is supported in the case of Heaney $v S,{ }^{75}$ where the ruling was that the description of a

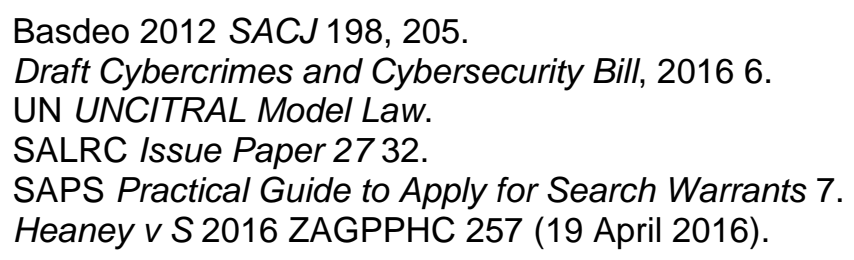

Basdeo 2012 SACJ 198, 205.

Draft Cybercrimes and Cybersecurity Bill, 20166.

UN UNCITRAL Model Law.

SALRC Issue Paper 2732.

SAPS Practical Guide to Apply for Search Warrants 7.

Heaney v S 2016 ZAGPPHC 257 (19 April 2016). 
suspected crime should be accurately described in line with the enabling legislation, and colloquially used terms should not be applied. The Electronic Communications and Transactions Act describes "data" as the electronic representation of information in any form, and "data messages" as data generated, sent, received or stored by electronic means. The SALRC further explains that in Part 2 of the UNCITRAL Model Law on Electronic Commerce (1996) it is stated that the concept of data messages is not intended to be limited to communication, but should include computer records and all types of messages that are generated, stored or communicated in a paperless form. ${ }^{76}$

For the purpose of this article, the definition of "data" is adapted from section 1 of the Electronic Communications and Transactions Act as is "the digital representation of information in any form", and not the "electronic representation of data in any form".

\subsection{Digital, computer, electronic or cyber evidence}

The SALRC observes that Article 2 of the UNCITRAL Model Law on Electronic Commerce refers to "data" and "data messages" rather than to "electronic evidence" or "digital evidence". ${ }^{77}$ The reason for this is obvious, since the Model Law on Electronic Commerce, which forms the basis of the South African Electronic Communications and Transactions Act, is aimed at regulating e-commerce, and only a small portion of it relates to defining criminal activities. The Model Law on Electronic Commerce stipulates that the law applies to all commercial activities. ${ }^{78} \mathrm{It}$ is therefore logical rather to use descriptions such as "data" or "data messages". Data or data messages become relevant during investigations into criminal activities, when "electronic evidence" or "digital evidence" should be used. Bouwer ${ }^{79}$ recommends that a single definition for "electronic evidence" should be adopted in the South African law as "information of probative value stored or transmitted in digital format".

References to "computer" evidence or "computer" crime seem to be outdated. ${ }^{80}$ The Model Law on Electronic Commerce and the Electronic Communications and Transactions Act make reference to data, data messages and information systems instead of "computer". The word

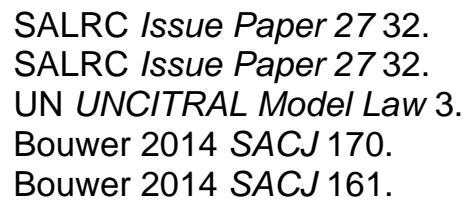


"computer" is well understood and is derived from what devices do, namely computing. ${ }^{81}$ Computers are defined as "electronic devices which are capable of receiving information (data) in a particular form and of performing a sequence of operations in accordance with a predetermined but variable set of procedural instructions (a programme) to produce a result in the form of information or signals". ${ }^{82}$ This definition differs vastly from any description of cellular phones with computing capabilities, which are described by the Oxford Dictionary as primarily telephones connected via cellular networks over a wide area. ${ }^{83}$

The term "cyber" is also of importance. In 1984 William Gibson originally coined the term "cyberspace" in his science fiction novel Neuromancer. ${ }^{84}$ The Oxford Dictionary defines "cyber" as "relating to or characteristic of the culture of computers, information technology, and virtual reality." 85

It is very difficult to differentiate between "electronic" and "digital". The SALRC shed light on this dilemma. ${ }^{86}$ The commission states that while these two terms are used interchangeably, an important distinction exists between the two - analogue and digital outputs. Examples of analogue outputs are vinyl records, photographic films and old telephone systems making use of switchboards. ${ }^{87}$ Neither the Electronic Communications and Transactions Act nor the Model Law on Electronic Commerce provides any description or definition of "electronic". Spencer 88 states that the term "electronic" is not particularly technical and has become synonymous with consumer electronics, such as clocks, radios, smartphones and tablets. It is therefore obvious that although "electronic devices" should include "data", the term is not exclusively limited to "data". However, "digital" is based on binary coding and functions as the building blocks of data. ${ }^{89}$ The Scientific Working Group on Digital Evidence (hereafter SWGDE) supports this by

81 Woodford $2007 \mathrm{http}: / /$ www.explainthatstuff.com/howcomputerswork.html.

82 Oxford English Dictionary 2016 http://www.oxforddictionaries.com/definition/english/ computer.

83 Oxford English Dictionary 2016 https://en.oxforddictionaries.com/definition/ cellular_phone.

84 Gibson Neuromancer.

85 Oxford English Dictionary 2016 https://en.oxforddictionaries.com/definition/cyber.

86 SALRC Issue Paper 2731.

87 Christensson $2005 \mathrm{http}: / /$ pc.net/helpcenter/answers/difference_between_analog and_digital.

88 Spencer 2014 https://www.quora.com/Whats-the-difference-between-electronic-anddigital.

89 Lowe Date Unknown http://www.dummies.com/how-to/content/digital-electronicsbinary-basics.html. 
defining "digital evidence" as evidence stored or transmitted in a binary form. ${ }^{90}$

For the purpose of this article, the term "digital" is used as opposed to the terms "electronic", "cyber" or "computer".

\subsection{Forensic duplicating processes in relation to originality}

Digital forensic investigations often involve creating and examining forensic duplicates of the data under analysis. ${ }^{91}$ Forensic investigators use forensic duplication techniques to collect or acquire data from hard drives, as opposed to the normal copying of files. This is because forensic duplicates contain all of the data from the source drive - even deleted files ${ }^{92} \mathrm{~A}$ normal copying process retrieves only the active or currently accessible files, not deleted files as well. ${ }^{93} \mathrm{~A}$ number of references were found to the concept of creating forensic duplicates of digital evidence, including copies, clones, bitstream copies, images, forensic copies, bit-by-bit copies, mirror images and acquisitions. Vandeven ${ }^{94}$ provides the following definitions for some of these concepts:

- Bit-by-bit or bit-stream copies - exact copies of all the bits of a logical volume or a physical drive. If the copies are made to files, it is referred to as forensic image files. If copies are made to another disk, it is referred to as clones or mirror images. The original and clones are identical and interchangeable, but if clones are not write-protected, subsequent actions of an analysis can alter the data.

- Disk image files - files containing exact copies of logical volumes or physical disks.

- Forensic images - exact copies of all the bits of logical volumes or physical drives that have been copied bit-by-bit and include all data and metadata. Forensic images include information, such as when these images were copied, by whom, with which forensic tools and the cryptographic hash used for verification of these images.

90 SWGDE 2012 https://www.swgit.org/pdf/SWGDE\%20and\%20SWGIT\%20Digital\% 20and\%20Multimedia\%20Evidence\%20Glossary?doclD=60 6 .

91 ACPO 1997 http://www.digital-detective.net/digital-forensics-documents/ACPO Good_Practice_Guide_for_Digital_Evidence_v5.pdf 4.

92 Nieman Search and Seizure 44.

93 Kerr 2005 Harv L Rev 540.

94 Vandeven 2014 https://www.sans.org/reading-room/whitepapers/forensics/forensicimages-viewing-pleasure-35447 32-35. 
- Raw images - exact bit-by-bit copies of disks into a single file. Raw images do not contain information regarding the creation of these images.

According to Gerber, ${ }^{95}$ forensic duplicates were previously also referred to as "mirror" images, but because the term confused courts, the use of "mirror" images is not recommended. Normally, mirror images are reverse images of originals.

All of these different terms can be confusing, but nowhere was it found in research that any of the terms used - except for "mirror copies" - has been rejected by courts.

In the light of the above, a single expression could prove to be technically incorrect in all situations. Whatever terminology is used, Lidbury and Boland ${ }^{96}$ state that what makes "collections" forensically sound should be the main aim - whether data were collected is an exact duplicate of the original source, including metadata. This implies that the collection method and subsequent analysis steps should not alter data and should include mechanisms to ensure the integrity of the data, such as the extraction of hash values. The judicial measures within a South African environment are the requirements specified by section 14 of the Electronic Communications and Transactions Act - the originality of data messages is measured against the integrity of digital evidence from the time the data were first generated. Integrity is assessed by considering whether the evidence has remained complete and unaltered except for the adding of endorsements or changes which are caused in the normal course of communication. Vacca ${ }^{97}$ states that an important feature of digital forensics is the fact that it changes the legal concept of best evidence. Vacca states that a new concept of representational accuracy has emerged in terms of digital evidence. It is not necessary anymore to present original copies. If forensic duplicates are created and the source data are depicted exactly, duplicates are considered original. ${ }^{98}$

In the Canadian case of $R \vee$ Munshi, ${ }^{99}$ it was stated that with the modernisation of technology, forensic duplication processes have developed to such an extent that duplicate originals can exist. Although this

95 Cited in Kessler Judges' Awareness 37.

96 Lidbury and Boland 2012 http://www.insidecounsel.com/2012/05/11/technologyforensically-sound-collection-of-esi 1.

97 Vacca Computer Forensics 795.

98 Vacca Computer Forensics 237.

$99 \quad R$ v Munshi 2002 CanLII 39110 (ON SC). 
ruling related to documents, the court stated that where exact replication processes are used, it is generally not necessary to compare original documents with the duplicate originals.

Van Deusen Phillips ${ }^{100}$ maintains that the test of establishing whether or not digital documents can stand as evidence is to determine or prove that the content of the documents is indeed the original, unchanged content. Van Deusen Phillips further states that this is normally accomplished by presenting the original documents or the duplicate originals. In the American case of Lorraine $v$ Markel American Ins Co, ${ }^{101}$ the court held that an original is the writing itself or a counterpart intended to have the same effect, and that if data are stored on computers or on similar devices, any printouts or other outputs readable by sight reflect the data accurately, the data can be accepted as original. In the case of Muller v BOE Bank Ltd, ${ }^{102}$ it was acknowledged that South African courts have accepted and are accustomed to the creation or existence of "copies" recognised as duplicate originals since the inception of carbon copies.

For the purpose of this article, the most elucidating description, which should make room for interpretation, is the creation of "forensically-sound duplicate original records" (hereafter forensic duplicates).

\section{Digital forensics and international standards}

\subsection{Digital forensics}

Many definitions of digital forensics exist. Palmer ${ }^{103}$ captures the main aspects as the use of scientifically-derived and proven methods in locating, collecting, preserving, analysing, interpreting, documenting and presenting digital evidence relating to incidents, often with the aim of presenting evidence during hearings. The goal of the process is to preserve evidence in its most original form while performing a structured analysis by collecting, identifying and validating digital information for the purpose of reconstructing past events.

\footnotetext{
100 Van Deusen Phillips 2010 https://crlgrn.wordpress.com/2010/07/27/legalconsiderations-for-electronic-evidence-part-5-original-vs-duplicate-documents-unfairprejudice/.

101 Lorraine v Markel American Ins Co (2007) 241 FRD 534, 544 (D Md 2007).

102 Muller v BOE Bank Ltd 20111 SA 252 (WCC).

103 Palmer 2001 https://isis.poly.edu/kulesh/forensics/docs/DFRWS_RM_Final.pdf 16.
} 
As a scientific-based discipline, digital forensics is premised on following set standards or methodologies in the processes defined above, which are susceptible to inspection by judiciaries. ${ }^{104}$

\subsection{International standards}

Nieman ${ }^{105}$ states that it is ironic that digital forensics first and foremost concerns forensic procedure, rules of evidence, legal concepts, precedents and processes and, second to this, computers. It is exactly because of this that standards in this field play such an important role.

Most of the "standards" are presented as guidelines as opposed to set standards. ${ }^{106}$

In the light of the importance of standards or the important role that standards should play in digital forensics as a science, it is surprising that there are no set standards, rules or a protocol for the handling of digital evidence, and that technical processes applied to digital evidence "do not have to pass any formal test" for digital evidence to be placed before courts. ${ }^{107}$ It is therefore understandable that the digital forensic industry has largely been self-regulated within a framework of internationally advised practices, case law, guidelines and industry groups.

\subsubsection{Principles of the Association of Chief of Police Officers}

The Good Practice Guide for Computer-Based Electronic Evidence ${ }^{108}$ of the ACPO was drafted in 1997. According to Mohay et al., ${ }^{109}$ these principles were reviewed during an International Hi-Tech Crime and Forensic Conference in October 1999 and were further formalised and accepted in 2001 at the $13^{\text {th }}$ International Criminal Organisation's (Interpol) Forensic Science Symposium.

Digital evidence should be accurate, authentic and admissible, like any other evidence, and should conform to common law and legislative principles. ${ }^{110}$ If investigators, for example, open files and make copies, move, save or print these files, these actions are not viewed as neutral, and

\footnotetext{
104 Casey Digital Evidence 10.

105 Nieman 2009 JILT 22.

106 IOS 2014 https://www.iso.org/standard/44407.html vi.

107 Scholtz Towards an Automated Digital Data Forensic Model 60.

108 ACPO 1997 http://www.digital-detective.net/digital-forensics-documents/ACPO_ Good_Practice_Guide_for_Digital_Evidence_v5.pdf.

109 Mohay et al Computer and Intrusion Forensics 123.

110 Nieman 2009 JILT 19.
} 
may influence or modify evidence. ${ }^{111}$ The Explanatory Report to the Cybercrime Convention indicates that digital evidence should be retained in the state it was found from the start to the point of prosecution. ${ }^{112}$ Kessler ${ }^{113}$ highlights the fact that each stage should be performed in such a way that the integrity of the evidence is preserved.

The ACPO principles have long been a guideline for digital forensic investigators in formulating digital forensic procedures to ensure that the requirements as listed above are met when evidence is collected, handled and managed. The guide contains the following four principles concerning the collection and management of digital evidence: ${ }^{114}$

- $\quad$ Principle 1: No actions taken by investigators should change the data that may subsequently be relied upon in court.

- $\quad$ Principle 2: Only in exceptional situations should investigators work with or access the original data and only if they are competent to do so and in a position to provide evidence explaining the relevance and the implications of their actions.

- Principle 3: All processes applied to the digital evidence by investigators should be fully recorded to enable independent third party experts to follow these processes and reach the same results.

- $\quad$ Principle 4: Investigators should ensure that all legal principles are adhered to during the analysis of digital evidence.

The principles provide guidelines so that the actions of investigators do not change the digital evidence under investigation, and if original evidence is accessed, this should be done by competent persons. A complete audit trail should be maintained so that the actions of investigators can be reviewed, assessed and evaluated against local legal requirements. These international principles were drafted with the aim of ensuring that the handling of digital evidence conforms to the requirements of evidence in terms of the law and especially to ensure that the integrity of evidence is maintained by ensuring that data have remained unaltered. ${ }^{115}$ The

\footnotetext{
Vacca Computer Forensics 19.

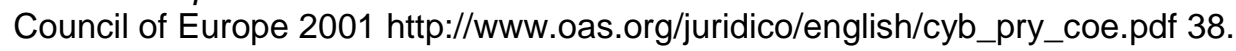
Kessler Judges' Awareness 6.

114 ACPO 1997 http://www.digital-detective.net/digital-forensics-documents/ACPO Good_Practice_Guide_for_Digital_Evidence_v5.pdf 4.

115 ACPO $1997 \mathrm{http}: / / \mathrm{www}$.digital-detective.net/digital-forensics-documents/ACPO_ Good_Practice_Guide_for_Digital_Evidence_v5.pdf 6-7.
} 
SALRC ${ }^{116}$ affirmed the importance of these principles when the commission stated that by accessing files, the actions of forensic investigators are not neutral and it is not easy to prove the integrity of digital evidence given the volatile nature of digital evidence. It has also been stated that the incorrect following of crime scene protocols and proper procedures can render digital evidence unusable or vulnerable to claims of prejudicial distortion by the defence.

\subsubsection{Standards and guidelines of the International Organisation of Standardisation}

3.2.2.1 ISO 27037 - Security Techniques - Guidelines for identification, collection, acquisition and preservation of digital evidence

In October 2012 the ISO 27037 Standard on Information Technology Security Techniques - guidelines for the identification, collection, acquisition and preservation of digital evidence was approved and published. The ISO standards are very well known, but even the ISO standards seem to shy away from setting rigid standards in a digital forensic environment. In the opening line of the scope of the ISO/IEC DIS 27037 Standard, ${ }^{117}$ it is stated that it merely provides "guidelines for specific activities in handling potential digital evidence; these processes are: identification, collection, acquisition and preservation of potential digital evidence".

The processes specified in the standard set guidelines to ensure that digital forensic investigators maintain the integrity of digital evidence during the collection phases of investigations by following analysis methodologies aimed at advancing the admissibility of evidence during legal processes. The importance of the integrity of evidence is supported by Kanellis, ${ }^{118}$ who emphasises that evidence should be managed correctly so that it cannot lose value and as a result, be inadmissible in courts. The ISO/IEC DIS 27037 Standard sets out four fundamental principles for procedures to be followed in collecting digital evidence. ${ }^{119}$ Digital forensic investigators should:

- Minimise the handling of original evidence.

116 SALRC Issue Paper 277.

117 IOS $2012 \mathrm{https}: / / \mathrm{www}$.iso.org/standard/44381.html 1.

118 Kanellis Digital Crime 58.

119 IOS 2012 https://www.iso.org/standard/44381.html 8. 
- Document all actions taken and account for any alterations in the data to allow experts to express an opinion regarding the reliability of the data.

- $\quad$ Adhere to local rules of evidence.

- Not take any actions beyond their competence.

The ISO/IEC DIS 27037 Standard specifies that, in most jurisdictions, digital evidence is governed by three primary principles: ${ }^{120}$

- Relevance

A standard requirement is that only relevant data should be collected. In other words, the data collected should assist in examining incidents or aspects of incidents at hand and there should be a need and a reason to collect the data. This requirement is supported by sections 28, 31 and 210 of the Criminal Procedure Act, which regulate wrongful searches and seizures, the inadmissibility of irrelevant evidence and the return of articles not required for criminal proceedings. Digital forensic investigators should be in a position to explain the procedures followed and validate the reasons and grounds why specific data were collected. Francoeur ${ }^{121}$ explains that any evidence should have an adequate level of relevance to the matter investigated.

- Reliability

All processes followed in handling digital evidence should be auditable and repeatable. The result of applying these processes should be reproducible by independent parties when they follow the same process. Hofman ${ }^{122}$ highlights that digital evidence should satisfy ordinary requirements related to the admissibility of documents. Documents should be authentic, reliable and original.

- $\quad$ Sufficiency

Digital forensic investigators should ensure that all relevant information is collected to ensure that the matter at hand can be sufficiently analysed and considered. Digital forensic investigators

120 IOS 2012 https://www.iso.org/standard/44381.html 6.

121 Francoeur J 2003 http://www.scribd.com/doc/276157/The-Principles-of-ElectronicAgreement-Legal-Admissibility-WP-8-07.

122 Hofman 2006 http://hofman@law.uct.ac.za 7. 
should be able to provide an indication of how much data was considered and should be able to justify the decision about what data and how much data to acquire.

The ISO/IEC DIS 27037 Standard specifies that all processes in relation to digital forensic investigations should be: ${ }^{123}$

- Auditable

All processes, procedures and results should be auditable by independent forensic investigators to evaluate the activities performed by digital forensic investigators. Audits can be facilitated if the processes and actions followed by digital forensic investigators are sufficiently documented. Digital forensic investigators should be able to explain the basis upon which decisions were taken and the choice of methodology followed during analyses.

- Repeatability

Repeatability is established when the same results are obtained in the following situations:

$\circ \quad$ when the same procedures and methods are used;

- when the same equipment under the same conditions is used.

It should be noted that repeatability is not possible in all situations - for example, where live data was analysed, or volatile memory. In this case, digital forensic investigators should ensure that acquisition processes are reliable.

- Reproducibility

Reproducibility is established when the same test results are produced under the following conditions:

- when the same method is used;

$\circ \quad$ when different equipment is used under different conditions;

- when the same results can be reproduced at any time after the original test. 
- Justifiability

Digital forensic investigators should be able to validate all actions and methods used in identifying, collecting, analysing and managing potential digital evidence. Justification can be achieved by demonstrating that their decisions were best practice in a specific case in obtaining all of the potential digital evidence in existing circumstances.

In terms of handling digital evidence, the ISO/IEC DIS 27037 Standard advises that "devices that may contain potential digital evidence [should be] removed from their original location to a laboratory or another controlled environment for later acquisition and analysis" and that forensic duplicates should be made for analyses to take place. ${ }^{124}$

The standard sets out a number of phases during digital forensic investigations, ${ }^{125}$ which directly relate to searches and seizures, namely:

- Identification - which includes the search for data storage devices, the recognition thereof and the documentation of processes followed. It also entails the prioritisation of the sequence of methods used to secure digital evidence, which can be volatile.

- Collection - which relates to the collection and removal of evidence or the acquisition of evidence on a scene.

- Acquisition - which entails the creation of forensically sound duplicates of evidence in the least restrictive manner possible.

- Preserving evidence - from the point of collection throughout all of the digital forensic processes followed.

These phases are described during the process of digital seizures and divided into two distinctly different stages, namely the search of physical devices on a scene and later searches for relevant data. ${ }^{126}$ To ensure that evidence is not compromised, forensic duplicates are created of originals, 
and it is the forensic duplicates that are analysed. ${ }^{127}$ The process followed in creating forensic duplicates should ultimately stand up to legal scrutiny. ${ }^{128}$

The collection of digital evidence is a forensic and procedural process which should always be performed with care. ${ }^{129}$ Data should be collected in such a way that the information is retained in the exact state in which it was found. ${ }^{130}$

Cross $^{131}$ explains that "acquisition" refers to the process of collecting digital evidence from specific devices, normally the computers of suspects or victims.

The process of creating forensic duplicates usually commences by removing the hard drive from the computer of the victim or suspect and by connecting the hard drive to a write-protector device. ${ }^{132}$ This procedure is in line with the principles set out by the $\mathrm{ACPO}^{133}$ and the $\mathrm{IOS}^{134}$ - the actions of investigators should not change data and, where possible, forensic duplicates should be made of the relevant data and these forensic duplicates should be analysed.

A write-protector device places a computer in a read-only form. ${ }^{135}$ This device prevents actions taken by investigators, such as opening and closing files or searching through files from influencing or changing metadata. This device allows digital forensic investigators to conduct preliminary searches on computers to establish whether these computers contain relevant information or not.

At this stage, evidence can be browsed to determine whether it contains relevant evidence or whether imaging can be started without browsing the evidence. Once it is determined that devices contain relevant evidence, forensic duplicates of the evidence should be made. This is done by means of a number of forensic software programs which allow digital forensic investigators to create forensic duplicates of devices. Nieman ${ }^{136}$ explains

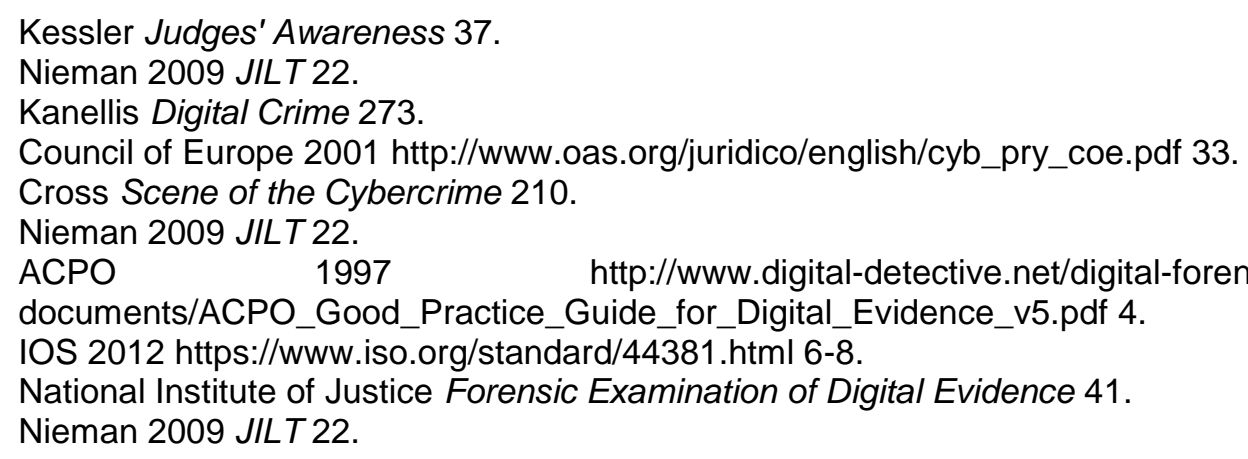


that bit-by-bit copies do exactly what the name suggests - copies are created bit-by-bit. A bit is the smallest size that data can be broken up into, an exact replica of every sector of a hard drive. Bit-by-bit copies are exact reproductions of digital records that contain all of the data, even hidden or deleted data. ${ }^{137}$ Forensic duplicates and original pieces of evidence are exact copies of one another based and proven on scientific principles, and they can therefore be considered as duplicate originals. ${ }^{138}$ With the current technology available, digital forensic investigators are able to collect a single file from a computer or a whole folder or the whole hard drive, including empty or unallocated space. ${ }^{139}$ To create forensic duplicates can be a lengthy process. According to the Digital Intelligence, ${ }^{140}$ an average transfer rate to create forensic duplicates is approximately 6GB per minute. If a hard drive is $500 \mathrm{~GB}$ in size, it therefore takes 83 minutes to create one forensic duplicate and another 83 minutes to verify the integrity of a forensic duplicate. Creating forensic duplicates of a server can easily take more than 12 to 24 hours.

During collection processes, forensic programmes use a cryptographic hashing algorithm to ascertain the hash value of data. This is referred to as the MD5 hash algorithm or SHA1 hash algorithm. Nieman ${ }^{141}$ correctly states that this hash value is often referred to as the electronic fingerprint of a piece of data.

The MD5 hash algorithm is a 128 bit hash value, while the SHA1 algorithm is a 160 bit hash value and the SHA1 hash is considered to be a more complex and more secure algorithm. ${ }^{142}$ Schneier ${ }^{143}$ explains that the MD5 hash value has a key size of 128 bits with $3.4 \times 1038$ possible combinations. The chance of randomly finding two files that produce the same hash value should be computationally unfeasible. Digital forensic investigators can therefore mathematically - beyond a reasonable doubt - show in court that digital evidence has not changed by even one character.

\footnotetext{
137 Angermeier $2010 \mathrm{~J}$ Crim L \& Criminology 1615.

138 Van Deusen Phillips 2010 https://crlgrn.wordpress.com/2010/07/27/legalconsiderations-for-electronic-evidence-part-5-original-vs-duplicate-documents-unfairprejudice/.

139 Vandeven 2014 https://www.sans.org/reading-room/whitepapers/forensics/forensicimages-viewing-pleasure-35447 1.

140 Digital Intelligence $2016 \quad$ https://www.digitalintelligence.com/products/ forensic_duplicator/.

141 Nieman 2009 JILT 22.

142 Thompson 2005 Digital Investigation 39.

143 Schneier Applied Cryptography 436-441.
} 
An example of hash values for the word "CAT" is:

MD5 hash value - c01ae1a5f122f25ce5675f86028b536a

SHA1 hash value - cf9b775c2c444520178d30c267440066c6eff6e8

Losey ${ }^{144}$ explains that if one single character in a computer is changed, the hash value changes. If the word "CAT" is changed, for example, to "CATS", the hash values change to:

MD5 hash value - ee77f71f2b809c0f6d92320fc9b480f6

SHA1 hash value - c7da99899675795b2f1d94607dbe57b731dd2255

Brown ${ }^{145}$ states that an imaging process is a scientific process and subject to the Daubert reliability test, ${ }^{146}$ which was formulated in Daubert $v$ Merrell Dow Pharmaceuticals, Inc. ${ }^{147}$ This scientific requirement is further discussed in the ISO/IEC DIS 27043 Standard below.

3.2.2.2 ISO/IEC 27043 Standard on Information Technology - Security techniques - Incident investigation principles and processes

The American Academy of Forensic Sciences identified digital forensics as a forensic science. ${ }^{148}$ As it is a scientific discipline, evidence prepared through digital forensics should meet the same standards as other scientific and technical evidence to be admissible in court. ${ }^{149}$ The final draft of the ISO/IEC 27043 Standard on information technology - Security techniques - Incident investigation principles and processes ${ }^{150}$ - specify that persons can be considered experts based on their experience, knowledge, skill, training or education. The opinions, theories, processes, procedures and tools used by experts should be evaluated against the Daubert test, ${ }^{151}$ which has for long been the de facto test in the United States of America and is applied by courts to scientific procedures used to prepare or uncover

\footnotetext{
144 Losey 2007 https://e-discoveryteam.com/school/computer-hash-5f0266c4c326 b9a1 ef9e39cb78c352dc/.

145 Brown Computer Evidence 28.

146 Kessler Judges' Awareness 4.

147 Daubert v Merrell Dow Pharmaceuticals, Inc 509 US 579 (1993).

148 AAFS 2008 http://www.aafs.org/students/choosing-a-career/types-of-forensicscientists-disciplines-of-aafs/.

149 Kessler Judges' Awareness 20.

150 IOS 2014 https://www.iso.org/standard/44407.html 4.

151 Daubert v Merrell Dow Pharmaceuticals, Inc 509 US 579 (1993).
} 
evidence. The Daubert test comprises the following factors that should be taken into account to ensure the integrity of evidence: 152

- The theories and techniques used by experts should have been tested.

- The theories and techniques should have been subjected to peer review and should appear in publications.

- Any error rates should be known to the experts and have been reported.

- Experts should be governed by standards governing their applications.

- The theories and techniques used by experts should enjoy widespread acceptance.

The ISO/IEC 27043 Standard expanded and sets out the different phases of a digital investigation. It is divided into two main areas, namely digital investigation processes and the concurrent or parallel processes depicted below. ${ }^{153}$ 
Figure 1 - Digital forensic processes ${ }^{154}$

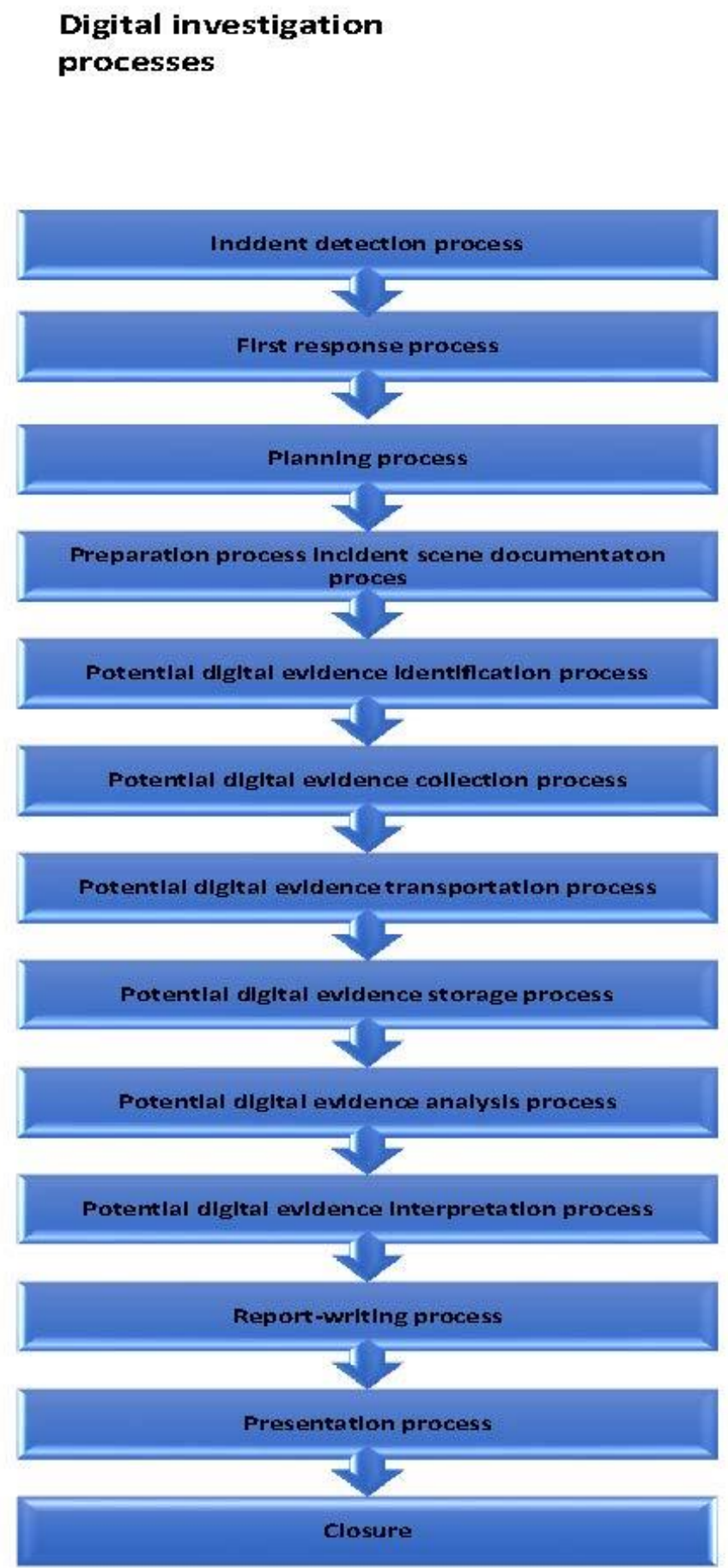

A summary of the different phases of a forensic investigation, ${ }^{155}$ as depicted in Figure 1, includes:

154 IOS 2014 https://www.iso.org/standard/44407.html 14. 
- Detection phase - incidents are detected.

- First responder phase - digital forensic investigators attend to incidents.

- $\quad$ Planning phase - investigations of incidents are planned.

- Preparation phase and scene documentation phase - preparation steps are taken to investigate incidents and document actions are taken on scenes.

- Evidence identification phase - potentially relevant evidence is identified.

- Evidence collection phase - evidence is collected.

- Evidence transportation phase - evidence is transported from scenes to digital forensic laboratories.

- Evidence storage phase - digital evidence is securely stored.

- Evidence analysis phase - evidence is analysed to determine its relevance.

- Evidence interpretation phase - evidence is interpreted in relation to its evidential value.

- Reporting phase - evidence is reported on.

- Presentation phase - testimonies or overviews are provided regarding the evidence.

- Closure phase - cases are archived.

The parallel processes include:

- Obtaining of authorisation to investigate incidents.

- Documentation of all actions during investigations.

- Continual information flow between digital forensic investigators and forensic investigators.

155 IOS 2014 https://www.iso.org/standard/44407.html 14-21. 
- Maintaining chain-of-custody.

- Preserving the integrity of evidence.

- Interaction with physical investigations.

Three of the parallel processes set out by the standard are of paramount importance:

\section{Obtaining authorisation}

Proper authorisation should be obtained for each process performed during an investigation. Authorisation may be required from government authorities, system owners, system custodians and principals. For the purpose of this article, proper authorisation is achieved through the application for search and seizure warrants in terms of the provisions stipulated in sections 20 and 21 of the Criminal Procedure Act.

\section{Preserving the chain of custody}

A traditional requirement for proving the integrity of evidence is the chain of custody. Van der Merwe et al. ${ }^{156}$ state that the prosecution needs to convince the court that the evidence was not interfered with from the time it was seized to the presentation in court. It is therefore critical that forensic investigators should ensure that digital evidence remains secure throughout the analysis. ${ }^{157}$

The chain of custody requirements were expanded upon in the ISO/IEC DIS 27037 Standard. These requirements relate to the ability of digital forensic investigators to account for all the acquired evidence from the point when it was within their custody. ${ }^{158} \mathrm{~A}$ chain of custody can be viewed as a record that chronologically captures the movements and handling of evidence. A chain of custody should contain:

- a unique identifier;

- a record of who accessed the evidence at what time and place;

- a record of who checked the evidence in or out of storage and for what reason or under whose authority;

156 Van der Merwe et al Information and Communications Technology Law 85.

157 Cross Scene of the Cybercrime 211.

158 IOS 2012 https://www.iso.org/standard/44381.html 10. 
- $\quad$ a record of any unavoidable changes made to the evidence, who made the changes and a justification for introducing the evidence to court.

Schetina, Green and Carlson, ${ }^{159}$ together with Lange and Nimsger, ${ }^{160}$ state the importance of a chain of custody in relation to the admissibility of digital evidence and say that courts need to be informed concerning the measures that were adhered to. A chain of custody ensures that evidence was not tampered with. Standard digital forensic processes - if followed and executed correctly - support and contribute to the chain of custody requirements.

\section{Conclusions}

It is evident that the uniqueness of digital evidence poses complications to traditional legal approaches. Digital evidence encompasses both tangible devices and intangible data and requires special methodologies to identify and collect all relevant evidence. The seizure of all data on computers can be viewed as a too extensive action due to the fact that not all of the relevant information is contained in files. It can reside in different locations on computers. The technical nature of cybercrimes and subsequent technical expert testimony adds further dynamics that are faced by digital forensic investigators.

The technical analysis and interpretation of terminology in relation to digital evidence are aspects that will be debated at length in South African courts in years to come. These interpretations can be problematic in terms of data, but a sound understanding can be gained from case law with regard to technical issues. It is argued that the "premises" described in search and seizure warrants should be the premises of suspects, and the interpretation of "search" should include actions in which the content of data becomes exposed. It is proposed that "search actions" such as look, locate, separate the information, interpret and analyse should be recognised. The creation of forensically-sound duplicate original records should constitute the seizure of data as items or articles of digital information in any form and should be recognised as original duplicates.

The originality, reliability, integrity and admissibility of digital evidence should be maintained as follows:

159 Schetina, Green and Carlson Internet Site Security 351.

160 Lange and Nimsger Electronic Evidence 76. 
- Data should not be changed or altered.

- Original evidence should not be directly examined.

- Forensically sound duplicates should be created.

- Digital forensic analyses should be performed by competent persons.

- Digital forensic analyses should adhere to relevant local legal requirements.

- Audit trails should exist consisting of all required documents.

- Chains of custody should be protected.

- $\quad$ Processes and procedures should be proper while recognised and accepted by the industry.

If the ACPO (1997) principles and ISO/IEC 27043 and 27037 Standards are followed as a forensic framework, then the actions of digital forensic investigators should be legally acceptable.

\section{Bibliography}

\section{Literature}

Angermeier 2010 J Crim L \& Criminology

Angermeier $\mathrm{V}$ "Swinging for the Fences: How Comprehensive Drug Testing, Inc. Missed the Ball on Digital Searches" 2010 J Crim L \& Criminology 15871632

Anon Current Policy and Procedure

Anon Current Policy and Procedure on Digital Search and Seizure by the SAPS [telephonic interview] (15 September 2016 Pretoria)

Basdeo Constitutional Perspective of Police Powers

Basdeo V Constitutional Perspective of Police Powers of Search and Seizure in the Criminal Justice System (LLM-thesis UNISA 2009)

Basdeo 2012 SACJ

Basdeo V "The Legal Challenges of Search and Seizure of Electronic Evidence in South African Criminal Procedure: A Comparative Analysis" 2012 SACJ 198-211 
Bouwer 2014 SACJ

Bouwer GP "Search and Seizure of Electronic Evidence: Division of the Traditional One-step Process into a New Two-step Process in a South African Context" 2014 SACJ 156-171

Brenner and Fredericksen 2002 Mich Telecomm \& Tech L Rev

Brenner SW and Fredericksen BA "Computer Searches and Seizures: Some Unresolved Issues" 2002 Mich Telecomm \& Tech L Rev 60-63, 8182

Brown Computer Evidence

Brown CLT Computer Evidence: Collection and Preservation $2^{\text {nd }}$ ed (Charles River Media Hingham 2010)

Casey Handbook of Computer Crime

Casey E (ed) Handbook of Computer Crime: Forensic Tools and Technology (Academic Press London 2000)

Casey Digital Evidence

Casey E (ed) Digital Evidence and Computer Crime: Forensics Science, Computers and the Internet $3^{\text {rd }}$ ed (Elsevier Amsterdam 2011)

Craiger and Shenoi Advances in Digital Forensics

Craiger JP and Shenoi S Advances in Digital Forensics III (International Federation for Information Processing New York 2007)

Cross Scene of the Cybercrime

Cross M Scene of the Cybercrime $2^{\text {nd }}$ ed (Syngress Publishing Arlington 2008)

Gibson Neuromancer

Gibson W Neuromancer (Phantasia Washington 1984)

Guzzi 2012 Am Crim L Rev

Guzzi $S$ "Digital Searches and the Fourth Amendment: The Interplay between the Plain View Doctrine and Search-protocol Warrant Restrictions" 2012 Am Crim L Rev 301-329

Hart 1958 Harv L Rev

Hart HLA "Positivism and the Separation of Law and Morals" 1958 Harv $L$ Rev 593-629

Jopek-Bosiacka 2011 Research in Language Jopek-Bosiacka A "Defining Law Terms: A Cross-cultural Perspective" 2011 Research in Language 9-29 
Kanellis Digital Crime

Kanellis P Digital Crime and Forensic Science in Cyberspace (Idea Group London 2006)

Kerr 2005 Harv L Rev

Kerr OS "Searches and Seizures in a Digital World" 2005 Harv L Rev 531585

Kerr 2005 Miss LJ

Kerr OS "Search Warrants in an Era of Digital Evidence" 2005 Miss LJ 85108

Kessler Judges' Awareness

Kessler G Judges' Awareness, Understanding, and Application of Digital Evidence (PhD-thesis Nova Southeastern University 2010)

Lange and Nimsger Electronic Evidence

Lange MCS and Nimsger KM Electronic Evidence and Discovery: What Every Lawyer should Know (ABA Chicago 2004)

Mohay et al Computer and Intrusion Forensics

Mohay GM et al Computer and Intrusion Forensics (Artech House Boston 2003)

National Institute of Justice Forensic Examination of Digital Evidence

National Institute of Justice Forensic Examination of Digital Evidence: A Guide for Law Enforcement (US Department of Justice Washington 2004)

Nieman Search and Seizure

Nieman A Search and Seizure, Production and Preservation of Electronic Evidence (PhD-thesis North West University 2006)

Nieman 2009 JILT

Nieman A "Cyberforensics: Bridging the Law / Technology Divide" 2009 JILT1-29

SALRC Discussion Paper 9

South African Law Reform Commission Discussion Paper 99, Project 108. Computer-related Crime: Preliminary Proposals for Reform in respect of Unauthorised Access to Computers, Unauthorised Modification of Computer Data and Software Applications and Related Procedural Aspects (SALRC Pretoria 2002) 
SALRC Issue Paper 27

South African Law Reform Commission Issue Paper 27, Project 126. Review of the Law of Evidence - Electronic Evidence in Criminal and Civil Proceedings: Admissibility and Related Issues (SALRC Pretoria 2010)

SAPS National Instruction 2/2002

South African Police Service National Instruction 2/2002: Search and Seizure (SAPS Pretoria 2002)

SAPS Practical Guide to Apply for Search Warrants

South African Police Service Practical Guide to Apply for Search Warrants in terms of Section 21 of the Criminal Procedure Act 51 of 1977 (SAPS Pretoria 2016)

Schetina, Green and Carlson Internet Site Security

Schetina ES, Green K and Carlson J Internet Site Security (Addison-Wesley Boston 2002)

Schneier Applied Cryptography

Schneier B Applied Cryptography, Second Edition Protocols, Algorithms and Source Code in C (Wiley New Jersey 1996)

Scholtz Towards an Automated Digital Data Forensic Model

Scholtz J Towards an Automated Digital Data Forensic Model with Specific Reference to Investigation Processes: A Survey of Actual and Desirable Practice (MCIS-thesis Auckland University of Technology 2009)

Silvernail 1997 Ala Law

Silvernail SJ "Electronic Evidence: Discovery in the Computer Age" 1997 Ala Law 176-177

Steytler Constitutional Criminal Procedure

Steytler N Constitutional Criminal Procedure: A Commentary on the Constitution of the Republic of South Africa (LexisNexis Butterworths Durban 2004)

Thompson 2005 Digital Investigation

Thompson E "MD5 Collisions and the Impact on Computer Forensics" 2005 Digital Investigation 36-40

UN UNCITRAL Model Law

United Nations UNCITRAL Model Law on Electronic Commerce with Guide to Enactment (United Nations New York 1996) 
Vacca Computer Forensics

Vacca JR Computer Forensics: Computer Crime Scene Investigation $2^{\text {nd }}$ ed (Charles River Media Hingham 2005)

Van der Merwe et al Information and Communications Technology Law Van der Merwe $\mathrm{D}$ et al Information and Communications Technology Law (LexisNexis Durban 2008)

Wang 2007 CSI

Wang SJ "Measures of Retaining Digital Evidence to Prosecute Computer Based Cybercrimes" 2007 CSI 216-223

\section{Case law}

\section{Canada}

$R$ v Munshi 2002 CanLII 39110 (ON SC)

$R v V u 20133$ SCR 657 (SCC)

\section{South Africa}

Bennett $v$ Minister of Safety and Security (TPD) (unreported) case number $10828 / 2005$ of 13 May 2005

Heaney v S 2016 ZAGPPHC 257 (19 April 2016)

Minister of Safety and Security v Bennett 20082 All SA 26 (SCA)

Minister of Safety and Security v Xaba 20031 All SA 596 (D)

Muller v BOE Bank Ltd 20111 SA 252 (WCC)

National Director of Public Prosecutions v Zuma 20081 All SA 197 (SCA)

Ntoyakhe $v$ Minister of Safety and Security 20001 SA 257 (E)

Powell v Van der Merwe 20051 All SA 149 (SCA)

Rudolph v Commissioner for Inland Revenue 19967 BCLR 11 (CC)

Thint (Pty) Ltd v National Director of Public Prosecutions, Zuma v National Director of Public Prosecutions 20091 SA 1 (CC)

\section{United States of America}

Arizona $v$ Hicks 480 US 321, 325 (1987)

Daubert v Merrell Dow Pharmaceuticals, Inc 509 US 579 (1993)

Lorraine v Markel American Ins Co (2007) 241 FRD 534, 544 (D Md 2007) 
United States v Flores-Lopez No 10-3803 (7th Cir 2012)

\section{Legislation}

\section{Australia}

Australian Crimes Act 12 of 1914

New Zealand

Search and Surveillance Act 24 of 2012

\section{South Africa}

Constitution of the Republic of South Africa, 1996

Criminal Procedure Act 51 of 1977

Draft Cybercrimes and Cybersecurity Bill, 2016

Electronic Communications and Transactions Act 25 of 2002

\section{International instruments}

Council of Europe Convention on Cybercrime (2001)

UNCITRAL Model Law on Electronic Commerce (1996)

\section{Internet sources}

AAFS 2008 http://www.aafs.org/students/choosing-a-career/types-offorensic-scientists-disciplines-of-aafs/

American Academy of Forensic Sciences 2008 AAFS Digital and Multimedia Sciences http://www.aafs.org/students/choosing-a-career/ types-of-forensic-scientists-disciplines-of-aafs/ accessed 5 January 2016

ACPO 1997 http://www.digital-detective.net/digital-forensics-documents/ ACPO_Good_Practice_Guide_for_Digital_Evidence_v5.pdf

Association of Chief Police Officers 1997 Good Practice Guide for Computer-Based Electronic Evidence Version 5 http://www.digitaldetective.net/digital-forensics-

documents/ACPO_Good_Practice_Guide_for_Digital_Evidence_v5.pdf accessed 27 December 2015

Chisum and Turvey 2000 http://www.profiling.org/journal/vol1_no1/ jbp_ed_january2000_1-1.html

Chisum WJ and Turvey BE 2000 Evidence Dynamics: Locard's Exchange Principle and Crime Reconstruction http://www.profiling.org/journal/ vol1_no1/jbp_ed_january2000_1-1.html accessed 29 January 2018 
Christensson 2005 http://pc.net/helpcenter/answers/difference_between_ analog_and_digital

Christensson P 2005 What is the Difference between Analog and Digital Technology? http://pc.net/helpcenter/answers/difference_between_ analog_and_digital accessed 10 December 2015

Clark and Connolly 2006 https://www.law.Georgetown. edu/academics/academic-programs/legal-writing-scholarship/

writing-center/upload/statutoryinterpretation.pdf

Clark K and Connolly M 2006 A Guide to Reading, Interpreting and Applying Statutes https://www.law.georgetown.edu/academics/academic-programs/ legal-writing-scholarship/writing-center/upload/statutoryinterpretation.pdf accessed 15 February 2016

Council of Europe 2001 http://www.oas.org/juridico/english /cyb_pry_coe.pdf

Council of Europe 2001 The Council of Europe Convention on Cybercrime: Status Quo and Future Challenges http://www.oas.org/juridico/english /cyb_pry_coe.pdf accessed 29 April 2016

Digital Intelligence 2016 https://www.digitalintelligence.com/products/ forensic_duplicator/

Digital Intelligence $2016 \quad$ Forensic Duplicator https://www.digitalintelligence.com/products/forensic_duplicator/ accessed 1 April 2016

Francoeur 2003 http://www.scribd.com/doc/276157/The-Principles-ofElectronic-Agreement-Legal-Admissibility-WP-8-07

Francoeur J 2003 The Principles of Electronic Agreement Legal Admissibility http://www.scribd.com/doc/276157/The-Principles-ofElectronic-Agreement-Legal-Admissibility-WP-8-07 accessed 14 June 2016

Forensic Handbook 2012 http://www.forensichandbook.com/locardsexchange-principle/

Forensic Handbook 2012 Locard's Exchange Principle http://www.forensichandbook.com/locards-exchange-principle/ accessed 16 July 2016

Forensics Library $2014 \mathrm{http}: / /$ aboutforensics.co.uk/edmond-locard/

The Forensics Library 2014 Edmond Locard http://aboutforensics.co.uk/edmond-locard/ accessed 12 December 2015 
Hofman 2006 http://hofman@law.uct.ac.za

Hofman J 2006 Electronic Evidence in South Africa http://hofman@law.uct.ac.za accessed 2 November 2014

IOS 2012 https://www.iso.org/standard/44381.html

International Organisation of Standardisation 2012 ISO/IEC 27037:2012 Information Technology - Security Techniques - Guidelines for Identification, Collection, Acquisition, and Preservation of Digital Evidence https://www.iso.org/standard/44381.html accessed 22 February 2016

IOS 2014 https://www.iso.org/standard/44407.html

International Organisation of Standardisation 2014 ISO/IEC 27043:2014 Information Technology - Security Techniques - Incident Investigation Principles and Processes https://www.iso.org/standard/44407.html accessed 22 February 2016

Lidbury and Boland 2012 http://www.insidecounsel.com/ 2012/05/11/technology-forensically-sound-collection-of-esi

Lidbury T and Boland M 2012 Technology: Forensically Sound Collection of ESI http://www.insidecounsel.com/2012/05/11/technology-forensicallysound-collection-of-esi accessed 13 January 2016

Losey 2007 https://e-discoveryteam.com/school/computer-hash5f0266c4c326b9a1ef9e39cb78c352dc/

Losey R 2007 e-Discovery Team Blog: Hash https://ediscoveryteam.com/school/computer-hash-

5f0266c4c326b9a1 ef9e39cb78c352dc/ accessed 16 July 2016

Lowe Date Unknown http://www.dummies.com/how-to/content/digitalelectronics-binary-basics.html

Lowe D Date Unknown Digital Electronics: Binary Basics http://www.dummies.com/how-to/content/digital-electronics-binarybasics.html accessed 2 September 2015

Oxford English Dictionary $2016 \quad$ https://en.oxford dictionaries.com/definition/cellular_phone
Oxford
English
Dictionary
2016
Cellular
Phone

https://en.oxforddictionaries.com/definition/cellular_phone accessed 23 October 2016

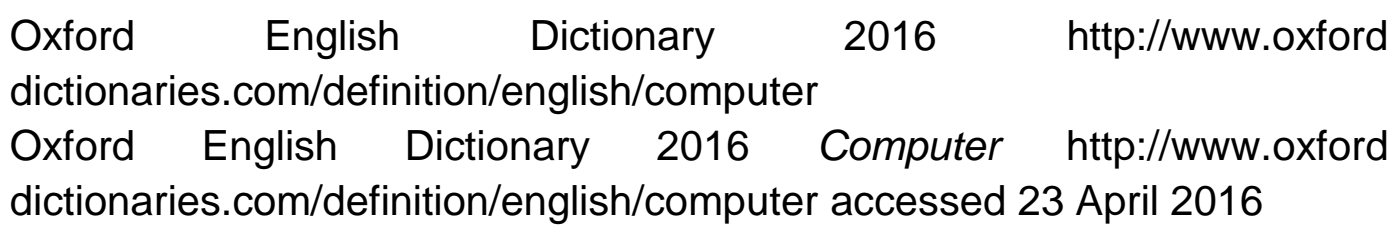


Oxford English Dictionary $2016 \quad$ https://en.oxford dictionaries.com/definition/cyber

Oxford English Dictionary $2016 \quad$ Cyber https://en.oxforddictionaries.com/definition/cyber accessed 23 October 2016

Palmer 2001 https://isis.poly.edu/kulesh/forensics/docs/DFRWS_RM_ Final.pdf

Palmer G 2001 A Road Map for Digital Forensic Research https://isis.poly.edu/kulesh/forensics/docs/DFRWS_RM_Final.pdf accessed 10 November 2015

Spencer 2014 https://www.quora.com/Whats-the-difference-betweenelectronic-and-digital

Spencer M 2014 What's the Difference between "Electronic" and "Digital"? https://www.quora.com/Whats-the-difference-between-electronic-anddigital accessed 23 May 2016

SWGDE 2012 https://www.swgit.org/pdf/SWGDE\%20and\%20SWGIT\% 20Digital\%20and\%20Multimedia\%20Evidence\%20Glossary?docID=60 Scientific Working Group on Digital Evidence 2012 SWGDE/SWGIT Digital and Multimedia Evidence Glossary https://www.swgit.org/pdf/SWGDE\%20 and\%20SWGIT\%20Digital\%20and\%20Multimedia\%20Evidence\%20Gloss ary?docID=60 accessed 3 May 2015

Van Deusen Phillips 2010 https://crlgrn.wordpress.com/2010/07/27/legalconsiderations-for-electronic-evidence-part-5-original-vs-duplicatedocuments-unfair-prejudice/

Van Deusen Phillips S 2010 The Documentalist - Legal Considerations for Electronic Evidence, Part 5: Original vs Duplicate Documents and Unfair Prejudice https://crlgrn.wordpress.com/2010/07/27/legal-considerationsfor-electronic-evidence-part-5-original-vs-duplicate-documents-unfairprejudice/ accessed 23 October 2015

Vandeven $2014 \quad$ https://www.sans.org/reading-room/whitepapers/ forensics/forensic-images-viewing-pleasure-35447

Vandeven S 2014 Forensic Images: For Your Viewing Pleasure https://www.sans.org/reading-room/whitepapers/forensics/forensicimages-viewing-pleasure-35447 accessed 2 October 2015

Woodford 2007 http://www.explainthatstuff.com/howcomputerswork.html Woodford C 2007 Computers http://www.explainthatstuff.com/ howcomputerswork.html accessed 22 February 2016 


\section{List of Abbreviations}

$\begin{array}{ll}\text { AAFS } & \text { American Academy of Forensic Sciences } \\ \text { ACPO } & \text { Association of Chief Police Officers } \\ \text { Ala Law } & \text { The Alabama Lawyer } \\ \text { Am Crim L Rev } & \text { American Criminal Law Review } \\ \text { CSI } & \text { Computer Standards and Interfaces } \\ \text { DNA } & \text { Deoxyribonucleic Acid } \\ \text { GB } & \text { Gigabyte } \\ \text { Harv L Rev } & \text { Harvard Law Review } \\ \text { IOS } & \text { International Organisation of Standardisation } \\ \text { J Crim L \& Criminology } & \text { Journal of Criminal Law and Criminology } \\ \text { JBP } & \text { Journal of Behavioral Profiling } \\ \text { JILT } & \text { Journal of Information, Law and Technology } \\ \text { Mich Telecomm \& Tech L L } & \text { Michigan Telecommunications } \\ \text { Rev } & \text { Technology Law Review } \\ \text { Miss LJ } & \text { Mississippi Law Journal } \\ \text { NLJ } & \text { New Law Journal } \\ \text { SACJ } & \text { South African Journal of Criminal Justice } \\ \text { SALRC } & \text { South African Law Reform Commission } \\ \text { SAPS } & \text { South African Police Service } \\ \text { SWGDE } & \text { Scientific Working Group on Digital Evidence } \\ \text { TB } & \text { Terabyte } \\ \text { UN } & \text { United Nations } \\ \text { UNCITRAL } & \text { United Nations Commission on International } \\ & \text { Trade Law }\end{array}$

